\title{
Mid-to-late Holocene climate change record in palaeo-notch sediment from London Island, Svalbard
}

\author{
Zhongkang Yang ${ }^{1,2}$, Liguang Sun ${ }^{1,2, *}$, Xin Zhou ${ }^{2}$ and Yuhong Wang ${ }^{2}$ \\ ${ }^{1}$ Anhui Province Key Laboratory of Polar Environment and Global Change, School of Earth and Space Sciences, \\ University of Science and Technology of China, Hefei 230026, China. \\ ${ }^{2}$ Institute of Polar Environment, School of Earth and Space Sciences, University of Science and Technology of \\ China, Hefei 230026, China. \\ *Corresponding author. e-mail: slg@ustc.edu.cn
}

MS received 19 June 2017; revised 10 September 2017; accepted 24 September 2017; published online 29 May 2018

The Arctic region is very sensitive to climate change and important in the Earth's climate system. However, proxy datasets for Arctic climate are unevenly distributed and especially scarce for Svalbard because glaciers during the Little Ice Age, the most extensive in the Holocene, destroyed large quantities of sediment records in Svalbard. Fortunately, palaeo-notch sediments could withstand glaciers and be well-preserved after deposition. In this study, we reconstructed a mid-to-late Holocene record of climate changes in a palaeo-notch sediment sequence from London Island. Multiple weathering indices were determined, they all showed consistent weathering conditions in the study area, and they were closely linked to climate changes. Total organic carbon (TOC) and total nitrogen (TN) were also determined, and their variation profiles were similar to those of weathering indices. The climate change record in our sediment sequence is consistent with ice rafting record from North Atlantic and glacier activity from Greenland, Iceland and Svalbard, and four cold periods are clearly present. Our study provides a relatively long-term climate change record for climate conditions from mid-to-late Holocene in Svalbard.

Keywords. Palaeo-notch sediment; mid-to-late Holocene; climate change; weathering indices; TOC and TN; Svalbard.

\section{Introduction}

The Arctic region plays a vital role in the Earth's climate system, and the Arctic climate and environmental changes are twice as fast as the global mean variations (Cohen et al. 2014; van der Bilt et al. 2015). The rapid climate warming in the Arctic exacerbates sea-ice loss and has a significant impact on the Arctic climate system, and the recent, frequent extreme weather events in mid-latitudes of the Northern Hemisphere are closely coupled with the Arctic amplification phenomenon (Cohen et al. 2014). However, instrumental climate records in the Arctic are rare and seldom more than 100 years long (Røthe et al. 2015). Long-term proxy records are needed to study the Arctic climate changes, and they are very valuable for evaluating future climate changes. Holocene climate record is increasingly regarded as a potential proxy to evaluate future Arctic climate

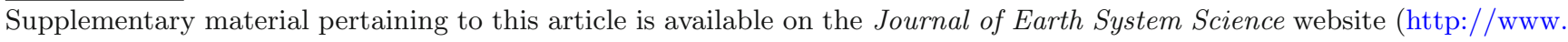
ias.ac.in/Journals/Journal_of_Earth_System_Science). 
changes in natural state (Wanner et al. 2011; van der Bilt et al. 2015).

The climate of the Holocene varied dramatically on multi-centennial to millennial timescale, unlike the earlier expectation of a relatively stable condition (Bond et al. 1997; Wanner et al. 2011). Bond et al. (1997) proposed a change cycle of approximate $1470 \pm 500$ years for Holocene climate based on ice rafted detritus (IRD) in the North Atlantic Ocean. Holocene experienced dramatic climate changes including several cold episodes, for example, '2.8 ka' cooling event (Bond et al. 1997; Plunkett and Swindles 2008), '4.2 ka' cooling event (Roland et al. 2014) and '5.8 ka' cooling event (Ojala et al. 2014). Many studies have been performed to reconstruct Holocene climate changes in the Arctic region (Moros et al. 2012; Perner et al. 2015). Alsos et al. (2016) reconstructed past vegetation and species diversity from Lake Skartjørna, Svalbard and assessed its resilience to Holocene climate change. Glacier variability and Holocene climate at Alaska and Svalbard were also reconstructed by McKay and Kaufman (2009) and van der Bilt et al. (2015). Nevertheless, climate records in $\mathrm{Ny}$-Ålesund during the Holocene are still very rare.

Marine, lacustrine and glacial sediments have been widely used to reconstruct palaeoclimatic changes, palaeoecological variability and glacier fluctuations (Bond et al. 1997, 2001; Sun et al. 2000a; Balascio et al. 2015; van der Bilt et al. 2015). However, available Arctic climate proxy datasets are scarce and unevenly distributed (Wanner et al. 2011; van der Bilt et al. 2015). Especially for $\mathrm{Ny}$ Alesund, it is very difficult to find well-preserved and long time span sediment sequences during mid-to-late Holocene, because glaciers in western Spitsbergen during the Little Ice Age had the largest extent during the Holocene, larger than during the Younger Dryas (Mangerud and Landvik 2007). The glacier advance greatly destroyed the sediment sequences in lakes and terraces, limiting our understanding of climate and environmental changes in Spitsbergen.

In this study, we collected a well-preserved palaeo-notch sediment sequence, a reliable proxy material for studying the palaeoclimate (Sun et al. 2005), and reconstructed the mid-to-late Holocene climate change in Ny-Ålesund, Svalbard.

\section{Study area}

Svalbard is a high Arctic archipelago located between $74-81^{\circ} \mathrm{N}$ and $10-35^{\circ} \mathrm{E}$ (figure 1), with an area of $63,000 \mathrm{~km}^{2}$. It includes Spitsbergen,

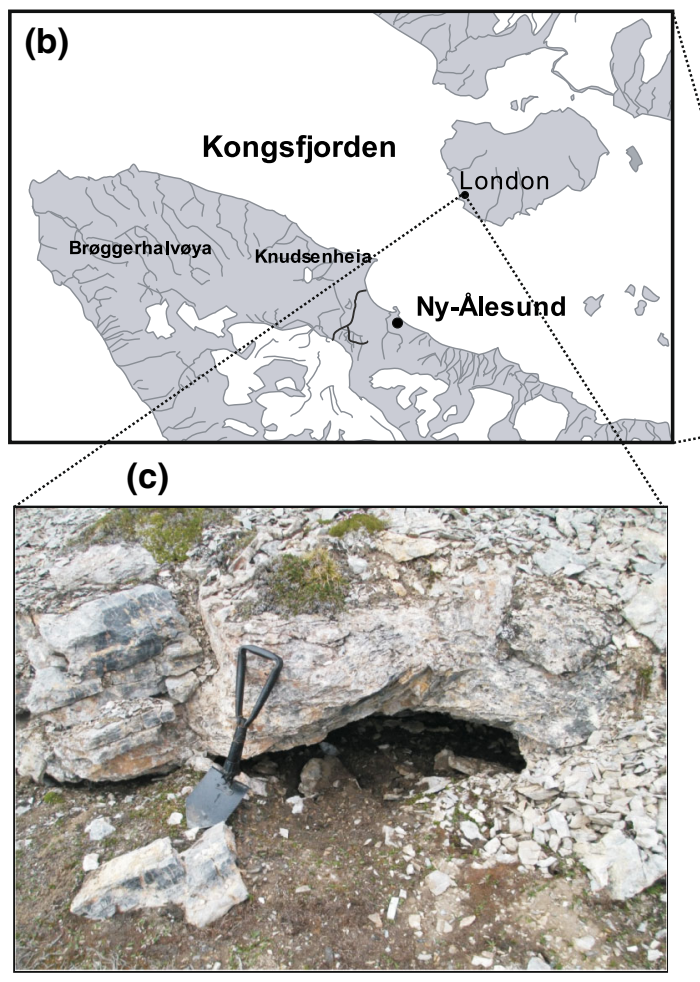

\section{(a)}

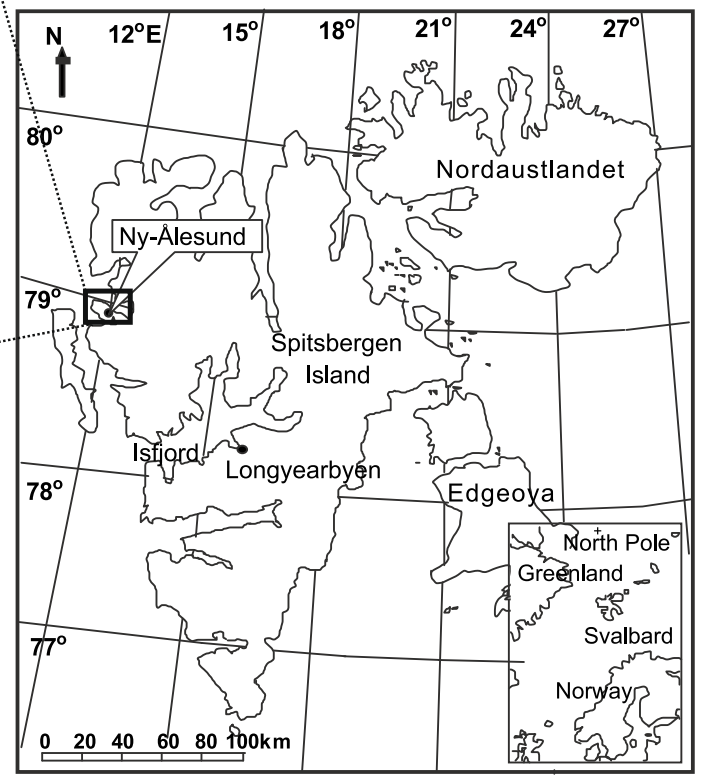

Figure 1. Map of our studied area and sampling site. (a) Location of Svalbard, (b) location of Ny-Ålesund, and (c) sampling site. 
Nordaustlandet, Edgeoya, and dozens of small islands. The largest island of Svalbard is Spitsbergen, with a total area of over $39,000 \mathrm{~km}^{2}$ (Hisdal 1998). About $60 \%$ of the land area of Svalbard is covered by glaciers, which are especially extensive in northeast part (Birks et al. 2004). The central and western areas are the most concentrated icefree areas of the island. Svalbard is sensitive to climate change due to its location near the interface of warm and cold waters between the Arctic and the world's oceans (Werner et al. 2016) and thus an ideal place for palaeoclimate studies.

$\mathrm{Ny}$-Ålesund $\left(78^{\circ} 55^{\prime} \mathrm{N}, 11^{\circ} 56^{\prime} \mathrm{E}\right)$ is located in the northwest of Svalbard, and London Island locates about $5 \mathrm{~km}$ to the north of $\mathrm{Ny}$-Ålesund (figure 1). West Spitsbergen Current flows northwards along western Svalbard, and coupled with much cyclonic activity it brings Svalbard a milder climate (Birks et al. 2004; Yuan et al. 2010). The mean annual temperature at $\mathrm{Ny}$-Ålesund is $-5.8^{\circ} \mathrm{C}$, about $6-7^{\circ} \mathrm{C}$ warmer than eastern Greenland of corresponding latitudes. In the western coast of Svalbard, the mean annual precipitation is about $400 \mathrm{~mm}$, and gradually decrease to $200-300 \mathrm{~mm}$ towards inland places (Hisdal 1998; Yuan et al. 2011).

\section{Materials and methods}

\subsection{Sample collection}

The sampling site $\left(78^{\circ} 57^{\prime} 46^{\prime} \mathrm{N}, 12^{\circ} 02^{\prime} 10^{\prime} \mathrm{E}\right)$, London Island, is about $5 \mathrm{~km}$ north of the Yellow River Station of China. We discovered a cave in the marine terrace of London Island which opens towards the sea and configuration of the cave is very similar to that of the palaeo-notch found in Antarctica (Sun et al. 2005). Based on the above characteristics, this cave is a palaeo-notch; it was formed by ocean wave before rising to the terrace, became exposed above sea level when the terrace uplifted or sea level decreased, and then began to receive deposit. Previous studies also indicated that palaeo-notch sediment was formed in lacustrine environment (Sun et al. 2005). The cave opens towards the southwest, and it is approximately $80 \mathrm{~cm}$ wide, $50 \mathrm{~cm}$ deep and $30 \mathrm{~cm}$ high.

A well-preserved palaeo-notch sediment profile was excavated using a small shovel and then sectioned at $2 \mathrm{~cm}$ intervals. It is a brown soil layer with a few angular gravels $(0.5-1.5 \mathrm{~cm})$, and there is no distinct difference for the lithology of the sediment profile. The sub-samples were labeled as
LDP-1-LDP-18, frozen and brought back to laboratory for analysis.

\subsection{Methods}

Each sample was air-dried in a clean laboratory and homogenized with a mortar and pestle, and then sieved through a 200 mesh sieve. For chemical element analysis, $50 \mathrm{mg}$ of powdered sample was weighed, and $1 \mathrm{ml}$ of hydrochloric and $0.5 \mathrm{ml}$ of hydrofluoric acids were added into the Teflon vessel. After sealing the vessel and leaving it to stand for more than $12 \mathrm{~h}$ at room temperature, the contents were transferred to a polypropylene bottle with $6 \mathrm{ml}$ of $4 \%$ (w/v) boric acid solution. The solution was finally diluted with water to $100 \mathrm{~g}$ and weighed. Then the samples were analyzed for $\mathrm{SiO}_{2}, \mathrm{Al}_{2} \mathrm{O}_{3}, \mathrm{Fe}_{2} \mathrm{O}_{3}, \mathrm{~K}_{2} \mathrm{O}, \mathrm{Na}_{2} \mathrm{O}, \mathrm{CaO}, \mathrm{MgO}$, $\mathrm{Sr}$, and $\mathrm{Ba}$ using inductively coupled plasma-optical emission spectrometry (ICP-OES). For determination of $\mathrm{CaO}$ in silicate phase, carbonate bearing samples were treated with $5 \%$ cold dilute $\mathrm{HCl}$ acid. Precision and accuracy of our results were monitored by analyzing sediment standard reference materials (GBW-7301a and GBW-7404) in every batch of analysis. The analyzed results of the standard reference materials were consistent with the reference values (table S1). The measured element data are shown in table 1.

For total organic carbon (TOC) and total nitrogen $(\mathrm{TN})$ analysis, about $0.1-0.5 \mathrm{~g}$ of powdered sample was precisely weighed to determine TOC content using chemical volumetric methods with a duplication error $<0.05 \%$ (Yuan et al. 2010). The precision and accuracy was monitored by standard reference materials (GBW-7301a and GBW-7404). TN was determined by NCSH elemental analyzer (varioEL) with an error of less than 1\%. The precision and accuracy was monitored by analyzing standard reference materials (Sulfanilic acid).

\section{Results}

\subsection{Chronology}

The chronology of the sediment profile LDP was established using AMS ${ }^{14} \mathrm{C}$ dating technique. Radiocarbon dating was performed on seven bulk sediment samples from the palaeo-notch sediment sequence. Six of them were determined at Center for Applied Isotope Studies, University of Georgia and the sample at the bottom labeled as LDP-18 was analyzed at A.E. Lalonde AMS 
Table 1. Major chemical compositions of the palaeo-notch sediment sequence.

\begin{tabular}{|c|c|c|c|c|c|c|c|c|c|c|}
\hline $\begin{array}{l}\text { Depth } \\
(\mathrm{cm})\end{array}$ & $\begin{array}{c}\mathrm{Sr} \\
(\mu \mathrm{g} / \mathrm{g})\end{array}$ & $\begin{array}{c}\mathrm{Ba} \\
(\mu \mathrm{g} / \mathrm{g})\end{array}$ & $\begin{array}{r}\mathrm{K}_{2} \mathrm{O} \\
(\%)\end{array}$ & $\begin{array}{c}\mathrm{Na}_{2} \mathrm{O} \\
(\%)\end{array}$ & $\begin{array}{c}\mathrm{MgO} \\
(\%)\end{array}$ & $\begin{array}{c}\mathrm{Fe}_{2} \mathrm{O}_{3} \\
(\%)\end{array}$ & $\begin{array}{r}\mathrm{CaO} \\
(\%)\end{array}$ & $\begin{array}{c}\mathrm{CaO}^{*} \\
(\%)\end{array}$ & $\begin{array}{c}\mathrm{Al}_{2} \mathrm{O}_{3} \\
(\%)\end{array}$ & $\begin{array}{c}\mathrm{SiO}_{2} \\
(\%)\end{array}$ \\
\hline 2 & 120.67 & 385.49 & 1.79 & 1.49 & 1.32 & 3.31 & 4.00 & 1.49 & 8.99 & 68.35 \\
\hline 4 & 110.00 & 398.79 & 1.86 & 1.45 & 1.37 & 3.71 & 2.67 & 1.45 & 9.53 & 68.74 \\
\hline 6 & 112.84 & 411.44 & 1.89 & 1.55 & 1.30 & 3.56 & 2.10 & 1.14 & 9.47 & 70.99 \\
\hline 8 & 115.77 & 385.94 & 1.71 & 1.66 & 1.04 & 2.85 & 1.93 & 1.08 & 8.69 & 76.17 \\
\hline 10 & 121.27 & 402.42 & 1.80 & 1.63 & 1.18 & 3.02 & 2.86 & 1.42 & 9.14 & 74.69 \\
\hline 12 & 125.48 & 402.43 & 1.87 & 1.44 & 1.32 & 3.18 & 4.47 & 1.44 & 9.13 & 69.03 \\
\hline 14 & 119.28 & 384.40 & 1.72 & 1.49 & 1.17 & 2.82 & 4.37 & 1.49 & 8.52 & 72.66 \\
\hline 16 & 126.63 & 379.75 & 1.77 & 1.47 & 1.48 & 2.93 & 5.70 & 1.47 & 8.84 & 69.07 \\
\hline 18 & 119.46 & 384.19 & 1.80 & 1.43 & 1.53 & 3.14 & 4.72 & 1.43 & 9.05 & 69.65 \\
\hline 20 & 109.34 & 411.43 & 1.95 & 1.44 & 1.43 & 3.52 & 3.03 & 1.44 & 9.78 & 71.33 \\
\hline 22 & 121.90 & 388.43 & 1.85 & 1.37 & 1.64 & 3.33 & 4.94 & 1.37 & 9.32 & 67.90 \\
\hline 24 & 137.80 & 353.85 & 1.64 & 1.42 & 1.89 & 2.72 & 8.17 & 1.42 & 8.38 & 68.03 \\
\hline 26 & 131.48 & 346.87 & 1.62 & 1.35 & 1.95 & 2.65 & 8.50 & 1.35 & 8.05 & 66.41 \\
\hline 28 & 127.38 & 364.72 & 1.71 & 1.41 & 1.88 & 2.85 & 6.10 & 1.41 & 8.63 & 69.43 \\
\hline 30 & 128.85 & 348.59 & 1.68 & 1.39 & 1.91 & 2.85 & 7.10 & 1.39 & 8.44 & 68.00 \\
\hline 32 & 128.85 & 363.12 & 1.73 & 1.32 & 1.91 & 3.03 & 7.38 & 1.32 & 8.70 & 66.69 \\
\hline 34 & 139.22 & 343.58 & 1.59 & 1.36 & 1.91 & 2.46 & 9.56 & 1.36 & 7.70 & 65.47 \\
\hline 36 & 147.18 & 328.92 & 1.52 & 1.37 & 1.96 & 2.34 & 11.74 & 1.37 & 7.45 & 65.52 \\
\hline
\end{tabular}

$\mathrm{CaO}^{*}$ represents $\mathrm{CaO}$ in silicate minerals only.

Laboratory, University of Ottawa. The carbon isotopic ratios were also measured during $\mathrm{AMS}{ }^{14} \mathrm{C}$ dating. Radiocarbon dates were calibrated using Clam 2.2 (Blaauw 2010) based on IntCal13 (Reimer et al. 2013; table S2). The AMS radiocarbon dates are expressed in conventional ${ }^{14} \mathrm{C}$ years before the present (BP), conventionally before 1950. An agedepth model (figure 2) for the sediment profile was created using Clam 2.2 (Blaauw 2010) and fitted using linear interpolation with temporal sampling resolution of $\sim 200$ years. The best fitted ages and $95 \%$ confidence intervals are plotted in figure 2 . The palaeo-notch started to deposit no later than $5700 \mathrm{BP}$ and stopped at around $1600 \mathrm{BP}$ according to the chronology.

\subsection{Weathering indices}

Silicate weathering indices such as Chemical Index of Alteration (CIA; Nesbitt and Young 1982), Plagioclase Index of Alteration (PIA; Fedo et al. 1995), and Chemical Index of Weathering (CIW; Harnois 1988) have been widely used to evaluate the weathering history of sediments. CIA is an excellent measure of chemical weathering degree of sediment or soil, and it is calculated using the following formula in molecular proportions

$$
\begin{aligned}
\mathrm{CIA}= & {\left[\mathrm{Al}_{2} \mathrm{O}_{3} /\left(\mathrm{Al}_{2} \mathrm{O}_{3}+\mathrm{CaO}^{*}\right.\right.} \\
& \left.\left.+\mathrm{Na}_{2} \mathrm{O}+\mathrm{K}_{2} \mathrm{O}\right)\right] \times 100
\end{aligned}
$$

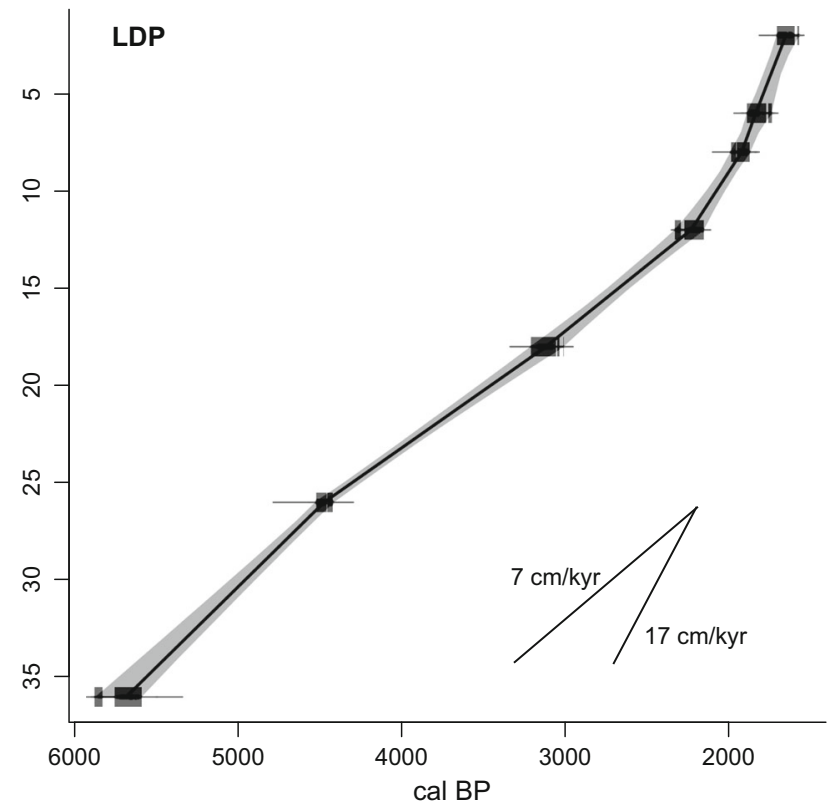

Figure 2. Age-depth model for the sediment profile LDP based on ${ }^{14} \mathrm{C}$ dating of bulk sediments at different depths.

where the $\mathrm{CaO}^{*}$ represents $\mathrm{CaO}$ in silicate minerals only (same for formula below). Thus correction to the measured $\mathrm{CaO}$ is necessary due to the presence of carbonate. McLennan (1993) proposed an approximate correction by assuming reasonable $\mathrm{Ca} / \mathrm{Na}$ ratios in silicate materials (table 1 ). The determined CIA values of the palaeo-notch sediment sequence fluctuate from 54.77 to 58.88, 


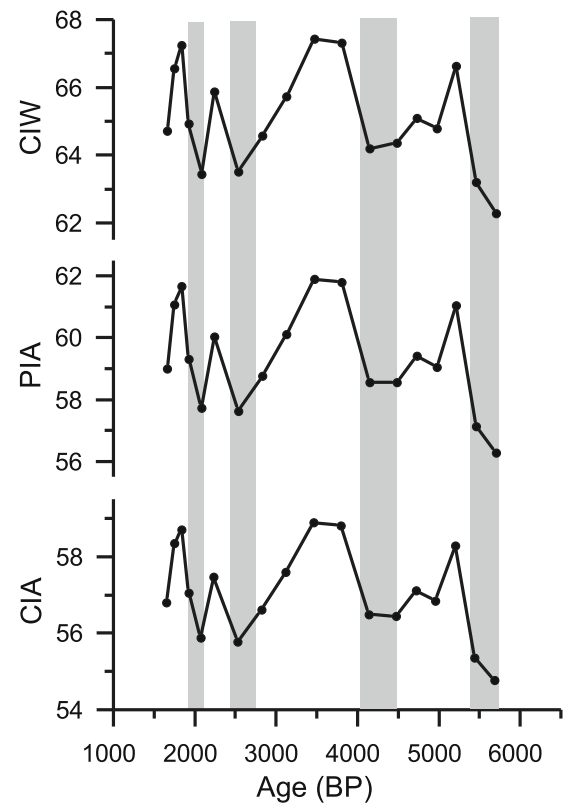

Figure 3. Temporal changes of commonly used weathering indices for palaeo-notch sediment sequence LDP in Svalbard.

with an average of 57.07. $\mathrm{K}$ in sediment or paleosols is more abundant than that in basement sources (Fedo et al. 1995) as a result of post-burial addition of $\mathrm{K}$ by metasomatism or illitization of clay minerals (Eze and Meadows 2013). CIW avoids this problem by excluding $\mathrm{K}$ from the CIA (Harnois 1988). However, rocks rich in K-feldspar are characterized by extremely high CIW values. PIA was proposed to monitor plagioclase weathering (Fedo et al. 1995). Weathering indices of CIW and PIA are calculated using the following formula in molecular proportions

$$
\begin{aligned}
\mathrm{CIW}= & {\left[\mathrm{Al}_{2} \mathrm{O}_{3} /\left(\mathrm{Al}_{2} \mathrm{O}_{3}+\mathrm{CaO}^{*}\right.\right.} \\
& \left.\left.+\mathrm{Na}_{2} \mathrm{O}\right)\right] \times 100 \\
\mathrm{PIA}= & {\left[\left(\mathrm{Al}_{2} \mathrm{O}_{3}-\mathrm{K}_{2} \mathrm{O}\right) /\left(\mathrm{Al}_{2} \mathrm{O}_{3}+\mathrm{CaO}^{*}\right.\right.} \\
& \left.\left.+\mathrm{Na}_{2} \mathrm{O}-\mathrm{K}_{2} \mathrm{O}\right)\right] \times 100
\end{aligned}
$$

The CIW values in the studied sequence are from 62.28 to 67.44 , with an average of 65.11 , while values of PIA vary from 56.29 to 61.90 , with an average of 59.39 (table S3).

All weathering indices in the palaeo-notch sediment sequence have similar profiles of weathering intensity (figure 3). There are four time periods characterized by weak chemical weathering intensity and thus cold environment, namely, 1900-2000, 2600-2700, 4100-4500 and 5400-5700 BP.

\subsection{TOC and $T N$}

The temporal changes of TOC and TN contents are very similar (table S3 and figure 4) and they are highly correlated with each other $\left(R^{2}=\right.$ $0.9031, P<0.01)$. The values of TOC and TN are relatively low from 5700 to $4000 \mathrm{BP}$ and high from 4000 to 1600 BP. Distinct depressions in TOC and TN values could be found around 1900, 2700, 4200 and $5700 \mathrm{BP}$.

The TOC level varies from 0.86 to $2.84 \%$, with an average of $1.86 \%$, while the TN content from 0.12 to $0.42 \%$, with an average of $0.25 \%$. Two periods are identified according to temporal changes in both TOC and TN contents. From 5700 to $4000 \mathrm{BP}$, the average value of TOC and TN is 1.30 and $0.18 \%$, respectively. The TOC and TN contents increase sharply from 5700 to $5400 \mathrm{BP}$ and then slightly decrease to a trough around $4000 \mathrm{BP}$. From 4000 to $1600 \mathrm{BP}$, the TOC and TN levels jump from 1.40 to $2.28 \%$ and 0.18 to $0.28 \%$, respectively. TOC and TN decline gradually until $2500 \mathrm{BP}$ and then increase rapidly except a trough around $1900 \mathrm{BP}$.

\section{Discussion}

\subsection{Sedimentary environment and formation history of the palaeo-notch}

The $\mathrm{C} / \mathrm{N}$ ratio has widely been used to identify organic matter sources in lacustrine sediment (Meyers 1994; Choudhary et al. 2009). Lacustrine algae have low atomic $\mathrm{C} / \mathrm{N}$ ratio (4-10) due to their high protein content, while the atomic $\mathrm{C} / \mathrm{N}$ ratio of terrestrial plants is higher (20 or greater) because of their high cellulose content (Meyers 1994). C/N ratios of the palaeo-notch sediment range from 7.8 to 10.2 (figure $5 \mathrm{a}$ ), within the range of organic matter from lacustrine algae. Carbon isotopic ratios are also very useful to trace sediment organic matter (Meyers 1994). The $\delta^{13} \mathrm{C}$ values and corresponding atomic $\mathrm{C} / \mathrm{N}$ ratios in the palaeo-notch sediment are plotted in figure $5 \mathrm{~b}$; they fall into or very close to values for lake algae, which indicate that organic matters of the palaeo-notch sediment are mainly from aquatic algae. In addition, $\mathrm{Sr} / \mathrm{Ba}$ ratios in the sediment sequence are less than 1 (figure 5a), indicating a fresh water lacustrine environment (Sun et al. 2000b, 2005). Thus the palaeo-notch sediment is accumulated in an aquatic environment, consistent with the finding in Antarctic that palaeo-notch 
sediments deposit in a lacustrine environment (Sun et al. 2005).

We proposed an outline for the formation of the palaeo-notch sediment sequence based on previous researches (Sun et al. 2005; Yuan et al. 2010, 2011). The Svalbard was totally covered by the Late Weichselian Barents ice sheet during the Last Glacial Maximum (Landvik et al. 1998). The Late Weichselian ice margin retreated to the coastline of western Svalbard around 13,000-12,000 BP. Since then, the islands gradually appeared and sea water could pour into the Kingsfjorden after the ice sheet retreat (Lehman and Forman 1992; Mangerud et al. 1992; Forman et al. 2004). The coast bedrock was constantly washed and eroded by ocean wave to form a rock notch (figure 6a). At around $10,000 \mathrm{BP}$, the relative sea-level of Broggerhalvoya dropped rapidly $(30 \mathrm{~m} / 1000$ year; Forman et al. $(1987,2004)$ to lift the rock notch above sea level (figure 6b). The ice sheet in the Kingsfjorden did not retreat thoroughly until $9440 \pm 130 \mathrm{BP}$. However, the sediment began to deposit around $5700 \mathrm{BP}$ and had a sedimentary hiatus of nearly 3700 years. The possible reason for the beginning of sediment is likely an extremely cold period around 5700 BP (Bond et al. 2001; van der Bilt et al. 2015); the terminal moraine caused by glacier advance in front of the rock notch acted as a dam to form a small pond and the same situation occurred in Fildes Peninsula, Antarctica (Sun et al. 2005), and thus the sedimentary process began (figure 6c). Climate became warmer around 1600 BP (Bond et al. 2001) and the dam was destroyed due to high water level in the pond or other external reasons. After that, the sediments in front of the palaeo-notch was gradually eroded and only those in the palaeo-notch were well preserved (figure 6d).
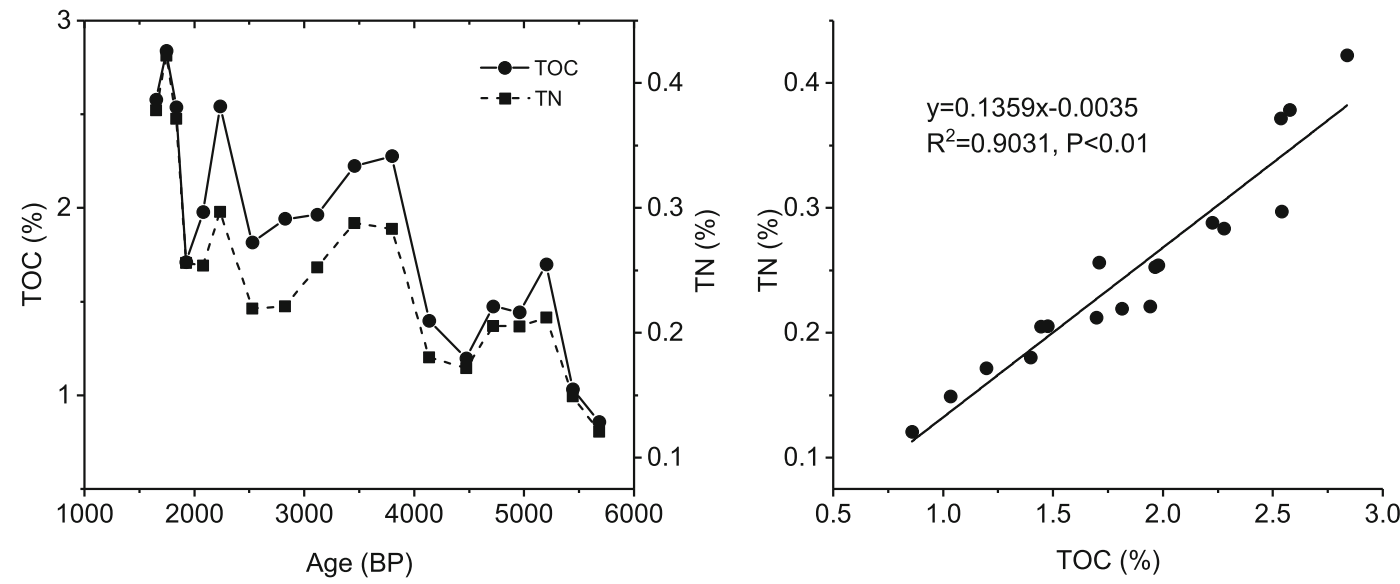

Figure 4. Temporal changes of TOC and TN in palaeo-notch sediment sequence LDP as well as their correlation between each other.

(a)

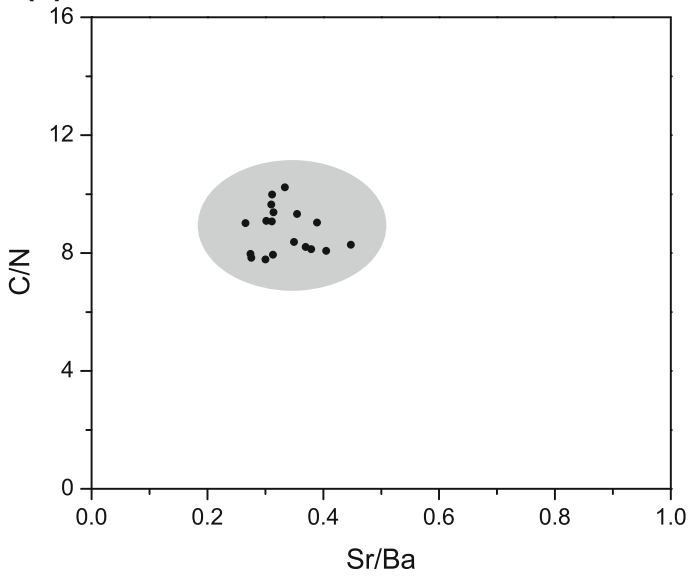

(b)

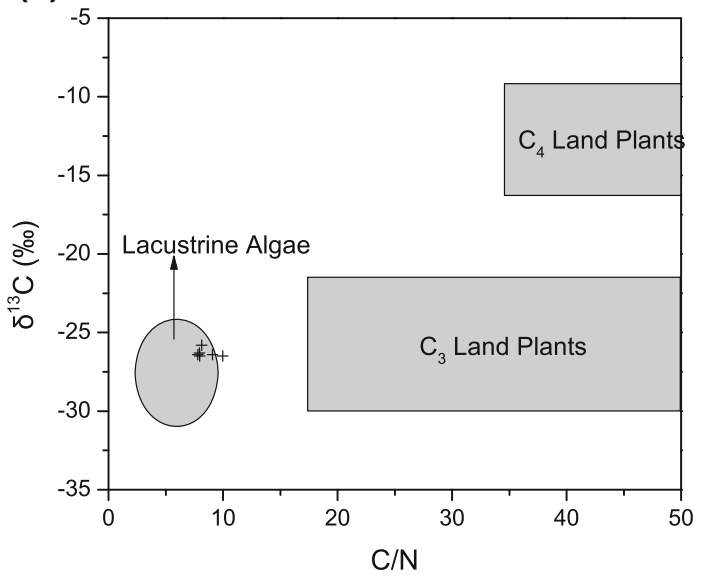

Figure 5. (a) $\mathrm{Sr} / \mathrm{Ba}$ and $\mathrm{C} / \mathrm{N}$ ratios of the sediment sequence $\mathrm{LDP}$, (b) $\mathrm{C} / \mathrm{N}$ atomic ratios and $\delta^{13} \mathrm{C}$ for lacustrine algae, $\mathrm{C}_{3}$ land plants, $\mathrm{C}_{4}$ land plants and sediments in the palaeo-notch (modified from Meyers 1994). 


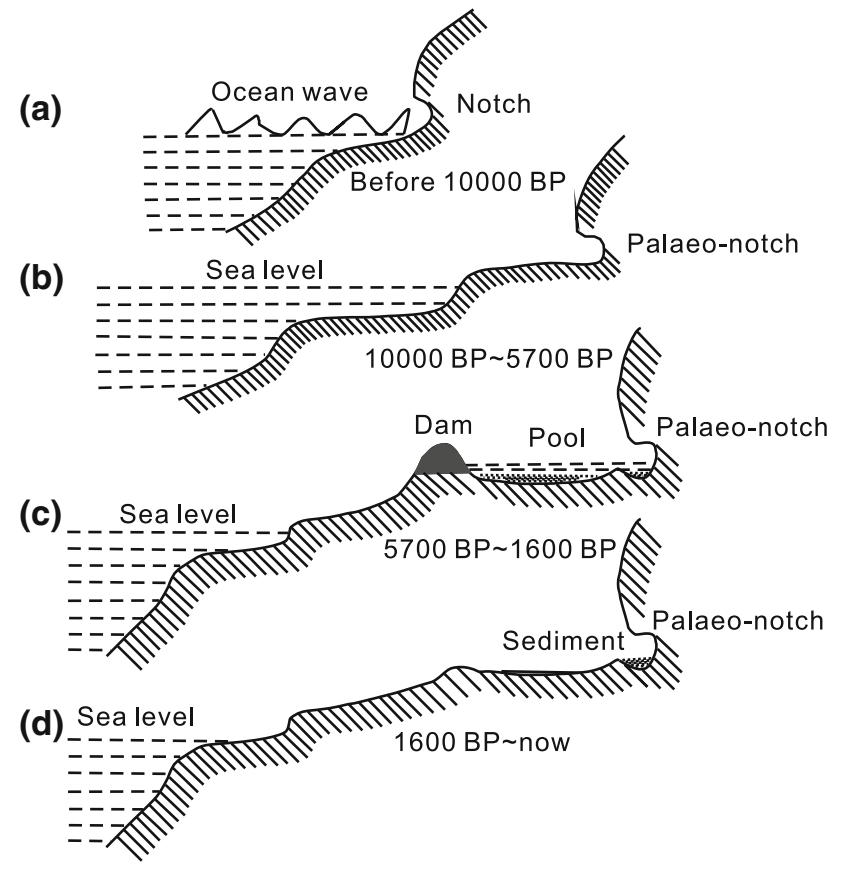

Figure 6. Schematic diagram for the formation process of the palaeo-notch. (a) Rock notch was caused by ocean wave erosion. (b) Rock notch was exposed after the terrace lifted. (c) Surrounding materials was carried to a catchment to deposit in the notch. (d) The dam was destroyed and the sediment was well-preserved in the notch.

\subsection{Weathering intensity}

Geochemical proxies of mineral alteration obtained from sediment analysis have been extensively used to determine the weathering conditions of source area (Garzanti and Resentini 2015). Chemical weathering strongly affects major element and mineralogy compositions of siliciclastic sediments (Nesbitt and Young 1982; McLennan 1993; Fedo et al. 1995). These chemical characteristics are ultimately recorded in sediments (Nesbitt and Young 1982; Selvaraj and Chen 2006). Therefore, well-preserved sediment sequence could provide an excellent proxy to study weathering history of sources area. Moreover, chemical weathering indices have been widely used for palaeoclimatic reconstructions (Garzanti and Resentini 2015); comparing to other proxy indices, they are more direct data for evaluating climate conditions because soil or sediment form at the Earth's surface and are in direct contact with climate conditions (Sheldon and Tabor 2009). Chemical weathering rates increase during warm and humid periods and decrease during cold and dry periods (Qiao et al. 2009).

Quantitative weathering indices have been proposed to monitor weathering conditions of different sediments. For example, silicate weathering indices such as CIA, PIA and CIW are preferred to measure the degree of chemical weathering (Fedo et al. 1995; Selvaraj and Chen 2006). High CIA values indicate great loss of labile cations such as $\mathrm{Ca}^{+}, \mathrm{Na}^{+}$and $\mathrm{K}^{+}$compared with stable constituents such as $\mathrm{Al}^{3+}$ and $\mathrm{Ti}^{4+}$, while low CIA values indicate deficient chemical alteration and reflect cold and arid conditions (Nesbitt and Young 1982; Fedo et al. 1995). Overall, the CIA values (figure 3) in our sediment sequence have a relatively low level, indicating weak chemical weathering and a cold climate and environment condition in the high Arctic. The CIA values are relatively high during 5250-5150, 3800-3500, 2350-2150 and 1900-1700 BP, suggesting an enhanced chemical weathering and warm climate condition. The CIA values have several valleys around 5700, 4200, 2700 and $1900 \mathrm{BP}$, corresponding to four cold periods (Bond et al. 1997; Levy et al. 2014). The weathering indices PIA and CIW, modified forms of CIA, are positively linked to CIA. Together, these indices provide a reliable chemical weathering history of London Island. Therefore, we standardized all three weathering indices to Z-score $(\mathrm{Z}=(\mathrm{X}-\mathrm{A}) / \mathrm{STD}$; here $\mathrm{X}$ is original value; $\mathrm{A}$ and STD are the averaged value and standard deviation of data series) and calculated the average as one weathering index (WI) to represent the weathering history of the studied area (figure 7 ).

\subsection{TOC as a palaeoclimate proxy}

Palaeo-notch sediment is deposited in a lacustrine environment, and it provides an excellent material for palaeoclimatic and palaeo environmental studies (Sun et al. 2005). In recent years, TOC and $\mathrm{TN}$ of lacustrine sediments have been extensively used as an indicator of palaeoclimate (Yoon et al. 2006; Melles et al. 2007; Choudhary et al. 2010; Kigoshi et al. 2014). TOC values in sediments can be largely dependent on initial primary production, post-depositional degradation and sedimentation rates (Schelske and Hodeli 1991; Choudhary et al. 2010). The palaeo-notch sediment is accumulated in a relatively enclosed environment with very weak wind-driven mixing of water, it has minimal amount of bioturbation, and it is good for preservation of organic matter (Melles et al. 2007; Vogel et al. 2013). Besides, many studies (e.g., Yoon et al. 2006; Melles et al. 2007; Vogel et al. 2013) have confirmed a positive correspondence between TOC content and climatic warmness. According to the 


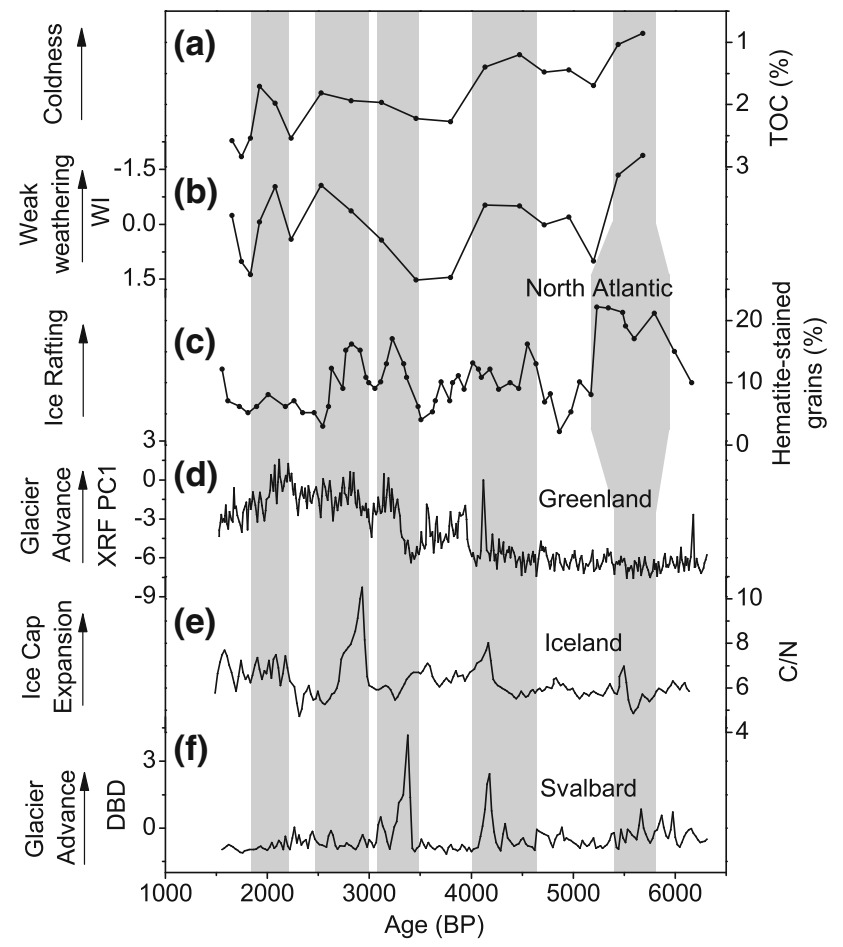

Figure 7. Palaeo-climate proxies in the North Atlantic region during mid-to-late Holocene. (a) Climate changes inferred from TOC content in palaeo-notch sediment sequence LDP. (b) Standardized weathering history proxy of Svalbard. (c) Variations of Hematite-stained grains from North Atlantic deep sea sediment core interpreted to indicate ice rafting events (Bond et al. 2001). (d) XRF PC1 data of Kulusuk Lake sediment in Greenland, a proxy interpreted to reflect Kulusuk glaciers activities (Balascio et al. 2015). (e) Carbon-nitrogen ratio of Hvítárvatn lake sediment in Iceland interpreted to indicate the size of Langjökull ice cap (Larsen et al. 2012). (f) Dry Bulk Density (DBD) changes of lake sediment in Svalbard interpreted to reflect past variations in glacier activity (van der Bilt et al. 2015). The grey bands mark the cold periods recorded in these proxies.

$\mathrm{C} / \mathrm{N}$ ratios, TOC of the palaeo-notch sediments mainly reflects the amount of organic detritus of aquatic origin; thus temporal change of TOC in this palaeo-notch sediment sequence is a potential indicator of climate changes in the study area. When the climate is relatively warm, the TOC value is high, and vice versa. Thus, the temporal changes of TOC indicate cold periods during 5700 5400, 4500-4100, 2700-2600 and 2000-1900 BP and warm periods during 5250-5150, 3800-3500, 2350-2150 and 1900-1700 BP in the study area, and they are consistent with the results from weathering intensity changes (figure 7 ).

\subsection{Palaeoclimate implications}

The Holocene climate changes in North Atlantic Ocean, Greenland and Iceland (Bond et al. 2001;
Harris et al. 2009; Larsen et al. 2012; Müller et al. 2012; Balascio et al. 2015; van der Bilt et al. 2015) have been evaluated in recent years. Evidences from North Atlantic deep sea sediment indicate that the Holocene climate experienced multiple cooling periods around 1400, 2800, 4200, 5900, 8100, 9400, 10,300 and 11,100 BP (Bond et al. 1997). These episodes may be related to changes in thermohaline circulation, solar activity, volcanic eruptions and melt water influence (Wanner et al. 2011). Our records from this palaeo-notch provide a better understanding of the mid-to-late Holocene climate changes in Svalbard.

We compared our records with other climate proxies from North Atlantic Ocean, Greenland, Svalbard and Iceland (figure 7) and found a good correspondence between cold climate periods and glacier advance, ice cap expansion as well as ice rafting events.

The cold period characterized by low TOC content and weak weathering during 5700-5400 BP in our record coincides with the onset of cold climate conditions around $5600 \mathrm{BP}$ inferred from pro-glacial lake sediment in Scores by Sund region, which marks the termination of Holocene thermal maximum (Funder 1978; Larsen et al. 2012). This is further supported by the ice rafting event during this period in North Atlantic region (Bond et al. 1997). The sedimentary ancient DNA record from Lake Skartjørna, Svalbard also indicate a transition from warm/moist conditions to colder/drier conditions around 6600-5500 BP (Alsos et al. 2016). This cooling event indicates a disproportionate environmental response to gradually decreasing solar insolation and may be related to changes in atmospheric or oceanic circulation (Larsen et al. 2012).

Around 5000-4000 BP, the TOC content is relatively low and the chemical weathering is weak in our record, indicating a cold climate. During the same period, glaciers began to expand in western Svalbard (Harris et al. 2009). In addition, a pro-glacial lake sediment in Svalbard also record a glacial advance at $4200 \mathrm{BP}$ (van der Bilt et al. 2015), corresponding to the ice rafting event at 4200 BP in North Atlantic Ocean (Bond et al. 1997). The cooling event is further supported by the glacier advance in Greenland (Balascio et al. 2015) and ice cap expansion in Iceland (Larsen et al. 2012) at $4200 \mathrm{BP}$.

The low TOC values and weak chemical weathering from 3500 to $2500 \mathrm{BP}$ (figure 7) indicate a cold period in Svalbard. The results are consistent 
with records from a pro-glacial lake sediment in Svalbard that suggest a glacier advance around 3300 BP. However, lack of moisture source makes it unfavorable for glacier growth after 3230 BP (van der Bilt et al. 2015), and climate changes in Svalbard after $3230 \mathrm{BP}$ are unlikely recorded in the pro-glacial sediment record. Marine record from Fram Strait indicates an increased sea ice cover and stronger influence of cold arctic waters during the comparable time period (Müller et al. 2012). Moreover, the Langjökull ice cap in Iceland advanced greatly around 2900 BP (Larsen et al. 2012) along with North Atlantic IRD events at 2800 BP (Bond et al. 1997). The Kulusuk glacier advanced as well in Greenland around 3200 and 2800 BP (Balascio et al. 2015).

The valley of TOC content around $1900 \mathrm{BP}$ in our record suggests a rapid cooling event. Ice expansion of Bregne ice cap in east Greenland at $\sim 1900 \mathrm{BP}$ has been documented (Levy et al. 2014) and the Kulusuk glacier in Greenland advanced at 2100 BP within chronological uncertainties (Balascio et al. 2015). Though lake sediment in Svalbard did not record glacier advance during this period due to lack of moisture source (van der Bilt et al. 2015), the sedaDNA taxon richness record from Lake Skartjørna (Alsos et al. 2016) and hydroclimate changes of High Arctic Svalbard (Balascio et al. 2016) revealed an abrupt shift to colder conditions around 1800 BP.

Holocene climate in Svalbard was governed by an alternation of forcings during different periods (van der Bilt et al 2016). The TOC and weathering intensity records in Svalbard indicate that climate was relatively warm from 5400 to $5200 \mathrm{BP}$, which is consistent with the calculated summer SST record in the eastern Fram Strait (figure 8; Werner et al. 2013). The onset of cold climate conditions since 5200 BP (figure 8) could be related to increased export of ice and cold Arctic water from the Arctic Ocean (Werner et al. 2013). The sustained cooling around $4400 \mathrm{BP}$ was caused by sea-ice expansion around Svalbard, driven by high seaice production and export in the Arctic (van der Bilt et al 2016). However, the climate from Svalbard decoupled from external (insolation) forcing and began to respond to North Atlantic Oscillation (NAO) since the onset of the Neoglacial period ( $4300 \mathrm{BP}$; van der Bilt et al 2016). The NAO is closely linked to the westerlies and thus the Atlantic water into the Nordic Seas (Andersen et al. 2004). During positive NAO phase, the climate in Svalbard is relatively warm due to warm moist air

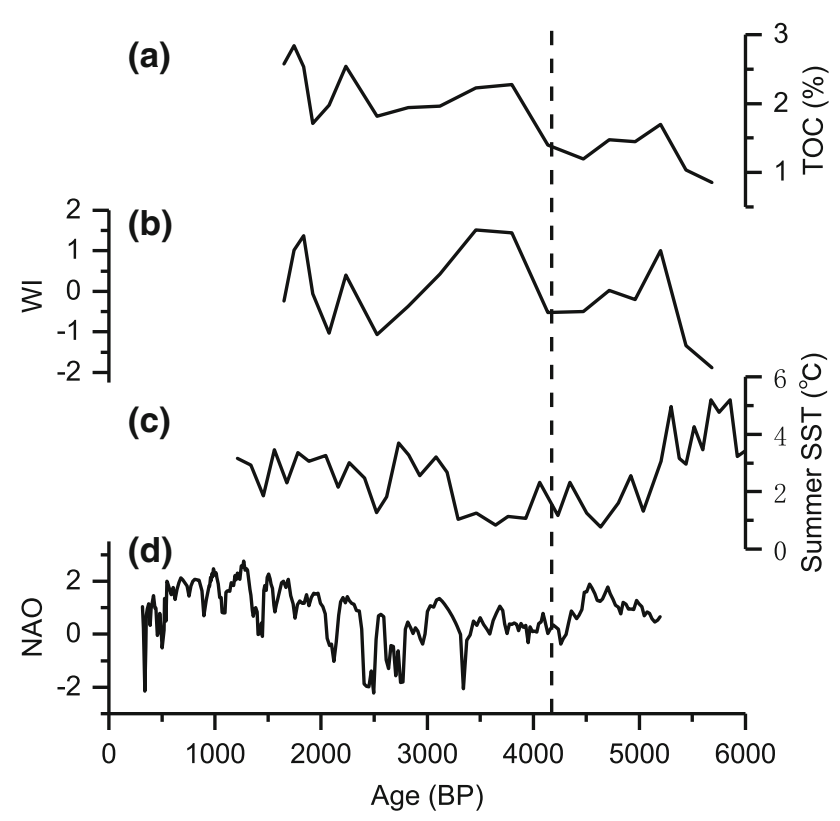

Figure 8. (a) Climate changes inferred from TOC content in palaeo-notch sediment sequence LDP. (b) Standardized weathering history proxy of Svalbard. (c) A SIMMAX-based summer SST reconstruction for the eastern Fram Strait (Werner et al. 2013). (d) Reconstructed NAO index for the past 5200 years (Olsen et al. 2012).

and water masses advected from low latitude by strengthening westerlies (van der Bilt et al 2016), and vice versa. The low-frequency NAO index (Olsen et al. 2012) changed from negative to positive conditions after $\sim 4300 \mathrm{BP}$, further confirmed the warm climate from 3800 to $3500 \mathrm{BP}$ in our record. The cold period around 2700-2600 and 200-1900 BP could be related to negative NAO conditions $\sim 2500$ and $2000 \mathrm{BP}$. The NAO stayed positive from 2500 to $1600 \mathrm{BP}$ except for these two negative NAO periods, which are consistent with the warm periods $2350-2150$ and $1900-1700$ BP in this study.

The stable and warm climate of the Holocene was interrupted by several cold episodes on multicentury scale. Besides, the mechanism of Holocene climate change in Svalbard varies during different periods (van der Bilt et al 2016). The mid-to-late Holocene climate changes reconstructed from the well-preserved palaeo-notch sediment sequence in this study help us to have a better understanding of climate dynamics in Svalbard during Holocene.

\section{Conclusions}

This study presents a reconstruction of mid-tolate Holocene climate changes on Svalbard through 
geochemical analysis of a palaeo-notch sediment sequence. Multiple weathering indices were determined, and they all showed consistent weathering conditions. The variation profiles of TOC and TN are similar to those of weathering indices. The chemical weathering indices, TOC and TN indicate four cold and four warm periods in the study area, and the inferred four cold periods (5700-5400, 4500-4100, 2700-2600 and 2000-1900 BP) are consistent with ice rafting events in the North Atlantic region and glacier activity in Greenland, Iceland and Svalbard. This study provides new proxy data for climate dynamics during mid-to-late Holocene in Svalbard.

\section{Acknowledgements}

The research was supported by Chinese Polar Environment Comprehensive Investigation and Assessment Programmes (CHINARE2017-02-01, CHINARE2017-04-04 and CHINARE2017-04-03). Sample information and data were issued by the Resource-sharing Platform of Polar Samples (http://birds.chinare.org.cn) maintained by Polar Research Institute of China (PRIC) and Chinese National Arctic and Antarctic Data Center (CN-NADC). We thank the Chinese Arctic and Antarctic Administration and PRIC for the logistic support in field.

\section{References}

Alsos I G, Sjögren P, Edwards M E, Landvik J Y, Gielly L, Forwick M, Coissac E, Brown A G, Jakobsen L V and Føreid M K 2016 Sedimentary ancient DNA from Lake Skartjørna, Svalbard: Assessing the resilience of arctic flora to Holocene climate change; The Holocene 26 627-642.

Andersen C, Koc N, Jennings A and Andrews J T 2004 Nonuniform response of the major surface currents in the Nordic Seas to insolation forcing: Implications for the Holocene climate variability; Paleoceanography 19, https://doi.org/10.1029/2002PA000873.

Balascio N L, D'Andrea W J and Bradley R S 2015 Glacier response to North Atlantic climate variability during the Holocene; Clim. Past 11 1587-1598.

Balascio N L, D'Andrea W J, Gjerde M and Bakke J 2016 Hydroclimate variability of high arctic Svalbard during the Holocene inferred from hydrogen isotopes of leaf waxes; Quat. Sci. Rev., https://doi.org/10.1016/j. quascirev.2016.11.036.

Birks H J B, Jones V J and Rose N L 2004 Recent environmental change and atmospheric contamination on Svalbard as recorded in lake sediments - an introduction; J. Paleolimnol. 3(1) 403-410.
Blaauw M 2010 Methods and code for 'classical' agemodelling of radiocarbon sequences; Quat. Geochronol. 5 $512-518$.

Bond G, Kromer B, Beer J, Muscheler R, Evans M N, Showers W, Hoffmann S, Lotti-Bond R, Hajdas I and Bonani G 2001 Persistent solar influence on North Atlantic climate during the Holocene; Science 2942130 2136.

Bond G, Showers W, Cheseby M, Lotti R, Almasi P, Priore P, Cullen H, Hajdas I and Bonani G 1997 A pervasive millennial-scale cycle in North Atlantic Holocene and glacial climates; Science 278 1257-1266.

Choudhary P, Routh J and Chakrapani G J 2009 An environmental record of changes in sedimentary organic matter from Lake Sattal in Kumaun Himalayas, India; Sci. Total Environ. 407 2783-2795.

Choudhary P, Routh J and Chakrapani G J 2010 Organic geochemical record of increased productivity in Lake Naukuchiyatal, Kumaun Himalayas, India; Environ. Earth Sci. 60 837-843.

Cohen J, Screen J A, Furtado J C, Barlow M, Whittleston D, Coumou D, Francis J, Dethloff K, Entekhabi D and Overland J 2014 Recent Arctic amplification and extreme mid-latitude weather; Nat. Geosci. 7 627-637.

Eze P N and Meadows M E 2013 Geochemistry and palaeoclimatic reconstruction of a palaeosol sequence at Langebaanweg, South Africa; Quat. Int. 376 75-83.

Fedo C M, Nesbitt H W and Young G M 1995 Unraveling the effects of potassium metasomatism in sedimentary rocks and paleosols, with implications for paleoweathering conditions and provenance; Geology 23 921-924.

Forman S, Lubinski D, Ingólfsson Ó, Zeeberg J, Snyder J, Siegert M and Matishov G 2004 A review of postglacial emergence on Svalbard, Franz Josef Land and Novaya Zemlya, northern Eurasia; Quat. Sci. Rev. 23 1391-1434.

Forman S L, Mann D H and Miller G H 1987 Late Weichselian and Holocene relative sea-level history of Bröggerhalvöya, Spitsbergen; Quat. Res. 27 41-50.

Funder S 1978 Holocene stratigraphy and vegetation history in the Scoresby Sund area, East Greenland; Grønlands Geologiska Undersøgelse Bulletin 129 66p.

Garzanti E and Resentini A 2015 Provenance control on chemical indices of weathering (Taiwan river sands); Sedim. Geol. 336 81-95.

Harnois L 1988 The CIW index: A new chemical index of weathering; Sedim. Geol. 55 319-322.

Harris C, Arenson L U, Christiansen H H, Etzelmüller B, Frauenfelder R, Gruber S, Haeberli W, Hauck C, Hoelzle $\mathrm{M}$ and Humlum O 2009 Permafrost and climate in Europe: Monitoring and modelling thermal, geomorphological and geotechnical responses; Earth Sci. Rev. 92 117-171.

Hisdal V 1998 Svalbard nature and history; Norsk Polarinsttutt, Oslo.

Kigoshi T, Kumon F, Hayashi R, Kuriyama M, Yamada K and Takemura K 2014 Climate changes for the past $52 \mathrm{ka}$ clarified by total organic carbon concentrations and pollen composition in Lake Biwa, Japan; Quat. Int. 333 2-12.

Landvik J Y, Bondevik S, Elverhøi A, Fjeldskaar W, Mangerud J, Salvigsen O, Siegert M J, Svendsen J I and Vorren T O 1998 The last glacial maximum of Svalbard and the Barents Sea area: Ice sheet extent and configuration; Quat. Sci. Rev. 17 43-75. 
Larsen D J, Miller G H, Geirsdóttir Á and Ólafsdóttir S 2012 Non-linear Holocene climate evolution in the North Atlantic: A high-resolution, multi-proxy record of glacier activity and environmental change from Hvítárvatn, central Iceland; Quat. Sci. Rev. 39 14-25.

Lehman S J and Forman S L 1992 Late Weichselian glacier retreat in Kongsfjorden, west Spitsbergen, Svalbard; Quat. Res. 37 139-154.

Levy L B, Kelly M A, Lowell T V, Hall B L, Hempel L A, Honsaker W M, Lusas A R, Howley J A and Axford Y L 2014 Holocene fluctuations of Bregne ice cap, Scoresby Sund, east Greenland: A proxy for climate along the Greenland Ice Sheet margin; Quat. Sci. Rev. 92 357-368.

Müller J, Werner K, Stein R, Fahl K, Moros M and Jansen E 2012 Holocene cooling culminates in sea ice oscillations in Fram Strait; Quat. Sci. Rev. 47 1-14.

Mangerud J, Bolstad M, Elgersma A, Helliksen D, Landvik J Y, Lønne I, Lycke A K, Salvigsen O, Sandahl T and Svendsen J I 1992 The last glacial maximum on Spitsbergen, Svalbard; Quat. Res. 38 1-31.

Mangerud J and Landvik J Y 2007 Younger Dryas cirque glaciers in western Spitsbergen: Smaller than during the Little Ice Age; Boreas 36 278-285.

McKay N P and Kaufman D S 2009 Holocene climate and glacier variability at Hallet and Greyling Lakes, Chugach Mountains, south-central Alaska; J. Paleolimnol. 41 143159.

McLennan S M 1993 Weathering and global denudation; J. Geol. 101 295-303.

Melles M, Brigham-Grette J, Glushkova O Y, Minyuk P S, Nowaczyk N R and Hubberten H W 2007 Sedimentary geochemistry of core PG1351 from Lake El'gygytgyn - a sensitive record of climate variability in the East Siberian Arctic during the past three glacial-interglacial cycles; J. Paleolimnol. 37 89-104.

Meyers P A 1994 Preservation of elemental and isotopic source identification of sedimentary organic matter; Chem. Geol. 114 289-302.

Moros M, Jansen E, Oppo D W, Giraudeau J and Kuijpers A 2012 Reconstruction of the late-Holocene changes in the Sub-Arctic Front position at the Reykjanes Ridge, north Atlantic; The Holocene 22 877-886.

Nesbitt H and Young G 1982 Early Proterozoic climates and plate motions inferred from major element chemistry of lutites; Nature 299 715-717.

Ojala A E, Salonen V, Moskalik M, Kubischta F and Oinonen M 2014 Holocene sedimentary environment of a HighArctic fjord in Nordaustlandet, Svalbard; Pol. Polar Res. 35 73-98.

Olsen J, Anderson N J and Knudsen M F 2012 Variability of the North Atlantic Oscillation over the past 5,200 years; Nat. Geosci. 5808.

Perner K, Moros M, Lloyd J M, Jansen E and Stein R 2015 Mid-to-late Holocene strengthening of the East Greenland Current linked to warm subsurface Atlantic water; Quat. Sci. Rev. 129 296-307.

Plunkett G and Swindles G 2008 Determining the Sun's influence on Lateglacial and Holocene climates: a focus on climate response to centennial-scale solar forcing at 2800 cal. BP; Quat. Sci. Rev. 27 175-184.

Qiao Y, Zhao Z, Wang Y, Fu J, Wang S and Jiang F 2009 Variations of geochemical compositions and the paleoclimatic significance of a loess-soil sequence from Garzê County of western Sichuan Province, China; Chinese Sci. Bull. 54 4697-4703.

Røthe T O, Bakke J, Vasskog K, Gjerde M, D'Andrea W J and Bradley R S 2015 Arctic Holocene glacier fluctuations reconstructed from lake sediments at Mitrahalvøya, Spitsbergen; Quat. Sci. Rev. 109 111-125.

Reimer P J, Bard E, Bayliss A, Beck J W, Blackwell P G, Ramsey C B, Buck C E, Cheng H, Edwards R L, Friedrich M, Grootes P M, Guilderson T P, Haflidason H, Hajdas I, Hatte C, Heaton T J, Hoffmann D L, Hogg A G, Hughen K A, Kaiser K F, Kromer B, Manning S W, Niu M, Reimer R W, Richards D A, Scott E M, Southon J R, Staff R A, Turney C S M and van der Plicht J 2013 Intcal13 and Marine13 radiocarbon age calibration curves 0-50,000 years Cal BP; Radiocarbon 55 1869-1887.

Roland T P, Caseldine C J, Charman D J, Turney C S M and Amesbury M J 2014 Was there a '4.2 ka event' in Great Britain and Ireland - Evidence from the peatland record; Quat. Sci. Rev. 83 11-27.

Schelske C L and Hodeli D A 1991 Recent changes in productivity and climate of Lake Ontario detected by isotopic analysis of sediments; Limnol. Oceanogr. 36 961975.

Selvaraj K and Chen C T A 2006 Moderate chemical weathering of subtropical Taiwan: Constraints from solid-phase geochemistry of sediments and sedimentary rocks; J. Geol. 114 101-116.

Sheldon N D and Tabor N J 2009 Quantitative paleoenvironmental and paleoclimatic reconstruction using paleosols; Earth Sci. Rev. 95 1-52.

Sun L, Liu X, Yin X, Xie Z and Zhao J 2005 Sediments in palaeo-notches: Potential proxy records for palaeoclimatic changes in Antarctica; Palaeogeogr. Palaeoclimatol. Palaeoecol. 218 175-193.

Sun L, Xie Z and Zhao J 2000a A 3,000-year record of penguin populations; Nature 407858.

Sun L, Xie Z and Zhao J 2000b The characteristics of Sr/Ba and $\mathrm{B} / \mathrm{Ga}$ in Lake Sediments on the Ardley peninsula, maritime Antarctic; Mar. Geol. \& Quat. Geol. 4 44-46 (in Chinese with English abstract).

van der Bilt W G M, Bakke J, Vasskog K, D'Andrea W J, Bradley R S and Ólafsdóttir S 2015 Reconstruction of glacier variability from lake sediments reveals dynamic Holocene climate in Svalbard; Quat. Sci. Rev. 126 201218.

van der Bilt W G, D'Andrea W J, Bakke J, Balascio N L, Werner J P, Gjerde M and Bradley R S 2016 Alkenonebased reconstructions reveal four-phase Holocene temperature evolution for High Arctic Svalbard; Quat. Sci. Rev., https://doi.org/10.1016/j.quascirev.2016.10.006.

Vogel H, Meyer-Jacob C, Melles M, Brigham-Grette J, Andreev A, Wennrich V, Tarasov P and Rosen P 2013 Detailed insight into Arctic climatic variability during MIS 11c at Lake El'gygytgyn, NE Russia; Clim. Past 9 1467-1479.

Wanner H, Solomina O, Grosjean M, Ritz S P and Jetel M 2011 Structure and origin of Holocene cold events; Quat. Sci. Rev. 30 3109-3123.

Werner K, Müller J, Husum K, Spielhagen R F, Kandiano E S and Polyak L 2016 Holocene sea subsurface and surface water masses in the Fram Strait-Comparisons of 
temperature and sea-ice reconstructions; Quat. Sci. Rev. $147194-209$.

Werner K, Spielhagen R F, Bauch D, Hass H C and Kandiano E 2013 Atlantic Water advection versus sea-ice advances in the eastern Fram Strait during the last 9 ka: Multiproxy evidence for a two-phase Holocene; Paleoceanography 28 283-295.

Yoon H, Khim B, Lee K, Park Y and Yoo K 2006 Reconstruction of postglacialpaleoproductivity in Long Lake,
King George Island, West Antarctica; Pol. Polar Res. 3 189-206.

Yuan L, Sun L, Long N, Xie Z, Wang Y and Liu X 2010 Seabirds colonized Ny-Ålesund, Svalbard, Arctic 9,400 years ago; Polar Biol. 33 683-691.

Yuan L, Sun L, Wei G, Long N, Xie Z and Wang Y 2011 9,400 yr BP: The mortality of mollusk shell (Mya truncata) at high Arctic is associated with a sudden cooling event; Environ. Earth Sci. 63 1385-1393.

Corresponding editor: D SHANKAR 